\title{
ANALISIS PENGUKURAN DAN PELAPORAN BIAYA KUALITAS SEBAGAI ALAT PENGENDALIAN BIAYA KUALITAS PADA CV. BLACK CUP INDO UTAMA MANADO
}

\author{
Herman Pabusa ${ }^{1}$, Stanly Alexander ${ }^{1}$, Djeini Maradesa ${ }^{1}$ \\ ${ }^{1}$ Jurusan Akuntansi, Fakultas Ekonomi dan Bisnis, Universitas Sam Ratulangi, Jl. Kampus Bahu, Manado, \\ 95115, Indonesia \\ E-mail : hermanpabusa@gmail.com
}

\begin{abstract}
Quality costs are costs incurred by the company in order to improve product quality which refers to all costs incurred to prevent the occurrence of defective goods or costs that must be incurred due to defective goods. Quality costs can be divided into two groups, namely the first quality costs associated with control activities consisting of prevention costs and valuation costs and the second is costs associated with failure activities consisting of internal failure costs and external failure costs. This study aims to determine the measurement and reporting of quality costs as a quality cost control tool on the $C V$. Indo Utama Black Cup Manado. The research method used in this thesis research is a descriptive method in which the purpose of each data collected is analyzed then drawn a conclusion and the type of research used is descriptive qualitative. The results obtained that the measurement and reporting of quality costs on the CV. Indo Utama Manado Black Cup has not yet taken cost measurements and has not presented separate quality cost reporting, so it cannot be used as a quality cost control tool.
\end{abstract}

Keywords: analysis; measurement and reporting; cost of quality

\section{PENDAHULUAN}

Pada masa sekarang ini era globalisasi telah mengubah wajah dunia, dengan tuntunan konsumen atas peningkatan kualitas produk dan jasa. Perkembangan dunia usaha ini dapat memberikan peluang bisnis yang sangat besar tetapi juga memberikan tantangan dan ancaman yang patut diperhitungkan atau diwaspadai, yaitu berupa persaingan. Salah satu usaha yang dilakukan perusahaan agar dapat bersaing adalah meningkatkan kualitas hasil produksinya. Perusahaan yang bersaing di pasar global adalah perusahaan yang mampu menghasilkan produk baik barang maupun jasa yang berkualitas tinggi dengan harga yang bersaing serta pelayanan yang baik yang dapat diberikan kepada konsumen. Agar dapat memenangkan persaingan, ada dua aspek yang harus diperhatikan yaitu, kualitas dan fleksibel. Kualitas merupakan salah satu kunci dalam memenangkan persaingan dengan pasar. Ketika perusahaan telah mampu menyediakan produk berkualitas maka telah membangun salah satu fondasi untuk menciptakan kepuasan pelanggan. Sunyoto (2012:236) menyatakan bahwa kualitas merupakan suatu ukuran untuk menilai bahwa suatu barang atau jasa telah mempunyai nilai guna seperti yang dikehendaki atau dengan kata lain suatu barang atau jasa dianggap telah memiliki kualitas apabila berfungsi atau mempunyai nilai guna seperti yang diinginkan. Sedangkan, fleksibel yaitu perusahaan mampu menangkap kebutuhan dan keinginan pelanggan yang selalu berubah. Dengan kata lain arti fleksibel mengungkapkan bahwa perusahaan harus serba bisa mengikuti perkembangan jaman karena dalam berbisnis mau tidak mau harus menyesuaikan dengan situasi dan kondisi tertentu. Untuk mendapatkan produk yang berkualitas, maka harus ada strategi yang dilakukan oleh perusahaan dimana harus ada biaya yang dikeluarkan untuk mencegah terjadinya produk cacat atau yang disebut dengan biaya kualitas. 
Hansen et al. (2013:288) mengemukakan bahwa biaya kualitas (cost of quality) adalah biaya-biaya yang timbul karena mungkin atau telah terdapat produk yang kualitasnya buruk. Sedangkan, Garrison et al. (2013:82) mengemukakan bahwa biaya kualitas (quality cost) mengacu pada semua biaya yang terjadi untuk mencegah terjadinya barang cacat atau biaya yang harus dikeluarkan karena adanya barang cacat. Biaya tersebut dikeluarkan untuk meningkatkan kualitas dari produk. Jadi biaya kualitas adalah biaya yang berhubungan dengan penciptaan, pengidentifikasian, perbaikan, dan pencegahan kerusakan. Pihak manajemen memerlukan sumber informasi secara akurat yang dapat menunjukkan kondisi perusahaan terutama yang berkaitan dengan aktivitas penciptaan, pengidentifikasian, mempertahankan dan memperbaiki kualitas produksi. Hal itu bertujuan untuk mengetahui seberapa besar biaya yang telah dikeluarkan untuk mengendalikan kualitas dan melakukan pencegahan, serta berusaha menekan pemborosan-pemborosan biaya kualitas yang seharusnya tidak perlu terjadi. Untuk itu perlu dilakukan pengukuran dan pelaporan biaya kualitas, sehingga dapat digunakan sebagai alat bantu bagi pihak manajemen di dalam melakukan perencanaan dan pengendalian biaya kualitas.

Pengukuran dan pelaporan biaya kualitas merupakan suatu hal yang dipandang perlu mengingat peranannya didalam pencapaian efektifitas dan efisiensi biaya. Dengan adanya pengukuran dan pengendalian biaya kualitas dapat dijadikan sebagai alat untuk pengendalian biaya kualitas yang bertujuan untuk mengurangi pemborosan yang disebabkan oleh produk yang kualitasnya rendah. CV. Black Cup Indo Utama Manado merupakan salah satu perusahaan jasa boga yang bergerak dalam bidang layanan makanan dan minuman sehingga dalam operasionalnya harus benar-benar memperhatikan kualitas personal pemasaran yang menjadi ujung tombaknya. Namun perusahaan ini masih belum menyajikan pencatatan akuntansi yaitu laporan biaya kualitas yang dapat berguna untuk pengendalian biaya kualitas.

\section{TINJAUAN PUSTAKA}

Akuntansi manajemen. Akuntansi manajemen adalah bidang akuntansi yang berhubungan dengan pelaporan keuangan untuk pengguna internal yang merupakan pihak yang mempunyai banyak kepentingan dengan sistem akuntansi, informasi akuntansi yang dihasilkan, dan juga adalah pihak yang diberi tanggungjawab yaitu melaksanakan kegiatan perusahaan. Dunia et al. (2012:6) mengemukakan bahwa pengguna internal yang dimaksud adalah pengelola/manajemen perusahaan tingkat atas, tingkat menengah maupun tingkat bawah. Sedangkan, menurut Simamora (2012:1) menyatakan bahwa akuntansi manajemen merupakan proses pengidentifikasian, pengukuran, penghimpunan, penganalisaan, penyusunan, penafsiran, dan pengkomunikasian informasi keuangan yang digunakan manajemen untuk merencanakan, mengevaluasi dan mengendalikan kegiatan usaha sebuah organisasi, serta untuk memastikan penggunaan dan akuntabilitas sumber daya yang tepat.

Tujuan akuntansi manajemen. Menurut Supriyono (2011:32), pengelompokkan tujuan dalam akuntansi manajemen terbagi menjadi dua bagian, yaitu:

1. Tujuan primer, guna membantu para manajemen dalam pengambilan keputusan manajemen.

2. Tujuan sekunder, guna membantu manajemen dalam melaksanakan fungsi perencanaan, menjawab masalah bidang organisasi, melaksanakan fungsi pengendalian manajemen dan melaksanakan fungsi kegiatan manajemen.

Fungsi akuntansi manajemen. Fungsi manajemen adalah elemen-elemen dasar yang selalu ada dan berada dalam proses manajemen yang menjadi patokan bagi manajer dalam melaksanakan kegiatan untuk mencapai tujuan. Fayol (2013:1841-1925) menyatakan bahwa terdapat lima fungsi manajemen, yaitu: perencanaan (planning), pengorganisasian (organizing), pengarahan (directing), kordinasi (coordinating), dan pengawasan (controlling). 
Kualitas suatu produk yang baik adalah produk yang berkualitas. Seringkali pertimbangan yang digunakan oleh konsumen dalam membeli suatu produk dikaitkan dengan kualitas dari produk itu sendiri. Hansen et al. (2013:269) menyatakan kualitas adalah opersional produk atau jasa yang berkualitas adalah yang memenuhi atau melebihi harapan pelanggan, dengan kata lain, kualitas adalah kepuasan pelanggan.

Manfaat kualitas. Edvardson dalam buku Tjiptono dan Chandra (2011:171-173) menyatakan bahwa produktivitas biasanya selalu dikaitkan dengan kualitas dan profitabilitas. Meskipun demikian ketiga konsep tersebut memiliki penekanan yang berbeda-beda yaitu sebagai berikut:

1. Produktivitas menekankan pemanfaatan (utilisasi) sumber daya, yang seringkali diikuti dengan penekanan biaya dan rasionalisasi modal. Fokus utamanya terletak pada produksi/operasi.

2. Kualitas lebih menekankan aspek kepuasan pelanggan dan pendapatan. Fokus utamanya adalah customer utility.

3. Profitabilitas merupakan hasil dari hubungan antara penghasil (income), biaya, dan modal yang digunakan.

Standar kualitas. Diperlukan sebagai jaminan pengendalian kualitas agar mendapatkan produk yang berkualitas baik. Garrison et al. (2013:86) mengemukakan bahwa Standar ISO 9000 Internasional Standards Organization (ISO), yang bermarkas di Jenewa, Swiss, telah mengeluarkan panduan pengendalian kualitas yang dikenal sebagai standar ISO 9000. Raiborn dan Kinney (2011:424) mengemukakan bahwa terdapat 8 (delapan) prinsip yang terkandung dalam standar ISO menyiratkan topik antara lain yaitu, fokus pada pelanggan, kepemimpinan, keterlibatan karyawan, pendekatan proses, pendekatan sistem manajemen, perbaikan berkesinambungan, pendekatan faktual dalam pembuatan keputusan, dan hubungan yang saling menguntungkan dengan pemasok.

Biaya kualitas. Untuk mendapatkan produk yang berkualitas, maka harus ada strategi yang dilakukan oleh perusahaan dimana harus ada biaya yang dikeluarkan untuk mencegah terjadinya produk cacat atau yang disebut dengan biaya kualitas. Setiawan dan Ahalik (2014:35) menyatakan bahwa biaya kualitas merupakan biaya yang dikeluarkan perusahaan dalam rangka meningkatkan kualitas produk.

Kategori biaya kualitas. Siregar et al. (2013:288) menyatakan bahwa biaya kualitas dapat dibedakan menjadi dua kelompok, yaitu:

1. Biaya kualitas yang berkaitan dengan aktivitas pengendalian (control activity). Biaya pengendalian dipecah lagi kedalam sub kelompok menjadi menjadi 2 (dua) bagian yaitu:

a. Biaya pencegahan (Prevention cost)

b. Biaya penilaian (Appraisal cost)

2. Biaya yang berkaitan dengan aktivitas kegagalan (failure activity).

Biaya kegagalan dipecah lagi kedalam sub kelompok menjadi 2 (dua) bagian yaitu:

a. Biaya kegagalan internal (internal failure cost)

b. Biaya kegagalan eksternal (external failure cost).

Pengukuran biaya kualitas. Menurut Siregar et al. (2013:289) menyatakan bahwa biaya kualitas dapat juga diklasifikasikan menjadi dua menurut kemudahan dalam pengamatannya yaitu:

1. Biaya kualitas yang dapat diamati. Biaya kualitas yang dapat diamati merupakan biaya kualitas yang secara langsung dapat diukur dan biasanya datanya tersedia dalam laporan akuntansi perusahaan. Termasuk dalam kelompok ini adalah biaya pencegahan, biaya penilaian, kegagalan internal serta beberapa biaya yang termasuk dalam subkelompok kegagalan eksternal, misalnya biaya garansi dan pengamatan produk.

2. Biaya kualitas yang tersembunyi. Biaya kualitas tersembunyi merupakan biaya atas hilangnya kesempatan yang diakibatkan oleh rendahnya kualitas. Biaya ini biasanya tidak 
terdapat dalam laporan akuntansi. Selain itu biaya ini sulit diukur secara akurat jumlahnya. Sebagai contoh biaya kehilangan penjualan, kehilangan pangsa pasar, ketidakpuasan konsumen, dan biaya komplain pelanggan.

Pelaporan Biaya Kualitas. Menurut Garrison et al. (2013:84), laporan biaya kualitas merupakan langkah awal dalam program perbaikan kualitas, perusahaan menyusun laporan biaya kualitas yang memberikan sebuah perkiraan adanya konsekuensi keuangan dari adanya tingkat cacat produk yang ada di perusahaan. Laporan biaya kualitas (quality cost report) menguraikan biaya pencegahan, biaya penilaian, dan biaya kegagalan internal dan eksternal, yang timbul dari tingkat kecacatan produk atau jasa yang dihasilkan oleh perusahaan saat ini. Pelaporan informasi biaya kualitas juga dapat berupa laporan kinerja kualitas. Supriyono (2010:201) mengungkapkan bahwa laporan kinerja biaya kualitas mengukur realisasi perkembangan, program penyempurnaan kualitas dalam satu organisasi. Terdapat 4 (empat) jenis laporan kinerja kualitas yaitu: Laporan Standar Interim, Laporan Trend Satu Periode, Laporan Trend Periode Ganda, dan Laporan Jangka Panjang.

Penelitian terdahulu. Lestianingrum (2016) atas penelitian tentang pengendalian kualitas melalui kualitas pengukuran dan pelaporan biaya kualitas pada UD Guyub Santoso Blitar-Blitar menemukan bahwa penurunan biaya kualitas total adalah sebesar $8,61 \%$ untuk tahun 2012 ke tahun 2013 dan 13,34\% untuk tahun 2013 ke tahun 2014 sehingga hal tersebut menunjukkan bahwa pengendalian biaya kualitas yang dilakukan oleh UD Guyub Santoso Blitar sudah berhasil mengendalikan biaya-biaya yang berkaitan dengan kualitas dan juga mampu mencapai efisiensi biaya dari tahun ke tahun, namun kondisi tersebut harus dianalisis lebih lanjut karena analisis lebih lanjut dapat membantu manajemen untuk merencanakan pengembangan dan pengendalian kualitas ditahun-tahun yang akan datang.

\section{METODE PENELITIAN}

Penelitian yang dilakukan merupakan penelitian kualitatif. Penelitian kualitatif adalah suatu penelitian yang ditujukan untuk mendeskripsikan dan menggambarkan fenomenafenomena yang ada baik fenomena yang bersifat alamiah atau rekayasa manusia (Sukmadinata, 2013:60). Penelitian ini menggunakan jenis penelitian deskriptif dengan mengumpulkan data penelitian mengenai pengukuran dan pelaporan biaya kualitas sebagai alat pengendalian biaya kualitas pada CV. Black Cup Indo Utama Manado.

Sumber data yang digunakan dalam penelitian ini adalah data primer dan data sekunder. Data primer adalah sumber data yang secara langsung memberikan data kepada pengumpul data (Sugiyono, 2014:308). Data primer ini berupa catatan hasil wawancara yang diperoleh berupa gambaran umum objek penelitian yang terdiri dari sejarah organisasi, visi dan misi instansi, struktur organisasi, tugas dan tanggung jawab dan hasil wawancara dengan pimpinan dari CV. Black Cup Indo Utama Manado mengenai pengukuran dan pelaporan biaya kualitas sebagai alat pengendalian biaya kualitas. Sedangkan, data sekunder merupakan sumber data yang tidak memberikan informasi secara langsung kepada pengumpul data (Sugiyono, 2014:131). Data sekunder berupa informasi-informasi tentang perusahaan dalam bentuk arsip maupun buku dan melalui studi dokumentasi dengan mempelajari berbagai tulisan dalam literatur-literatur yang berhubungan dengan penelitian.

\section{HASIL PENELITIAN DAN PEMBAHASAN \\ 4.1. Hasil Penelitian}

Biaya biaya-biaya yang ada pada CV. Black Cup Indo Utama. Adapun komponen biaya yang terdapat pada CV. Black Cup Indo Utama selama tahun 2017 sampai 2019 adalah sebagai berikut:

1. Biaya bahan baku. Biaya yang digunakan untuk memperoleh semua bahan baku yang akan digunakan untuk proses produksi. Besarnya biaya bahan baku ditentukan oleh biaya 
perolehannya yaitu pembelian sampai dengan biaya dapat digunakan dalam proses produksi.

2. Biaya tenaga kerja. Biaya yang dikeluarkan oleh perusahaan untuk pembayaran atas penyerahan jasa yang dilakukan oleh karyawan.

3. Biaya operasional. Biaya yang dikeluarkan oleh perusahaan diluar kegiatan proses produksi. Biaya operasional antara lain biaya administrasi dan umum yang dapat berupa: biaya listik dan air, biaya internet, dan biaya telepon.

4. Biaya renovasi. Biaya yang dikeluarkan oleh perusahaan untuk perbaikan aset tetap (gedung) yang rusak atau mengganti yang baik dengan maksud meningkatkan kualitas atau kapasitas.

5. Biaya pengerjaan ulang. Biaya yang dikeluarkan oleh perusahaan untuk memperbaiki kualitas produk karena adanya pesanan yang tidak sesuai dengan permintaan konsumen.

Laporan yang dihasilkan pada CV. Black Cup Indo Utama. Berdasarkan hasil pengamatan laporan-laporan yang dibuat oleh CV. Black Cup Indo Utama adalah sebagai berikut:

1. Laporan kas masuk, yaitu laporan keuangan perusahaan yang berisi aliran sumber-sumber dari mana kas diperoleh/ penerimaan tunai dari penjualan.

2. Laporan kas keluar, yaitu laporan keuangan perusahaan yang berisi tentang kebutuhan kas untuk pembayaran-pembayaran kegiatan operasional perusahaan.

\subsection{Pembahasan}

Analisis pengukuran biaya kualitas pada CV. Black Cup Indo Utama. Dalam rangka untuk mengidentifikasi biaya, biaya-biaya yang ada akan dianalisis satu persatu apakah biaya tersebut dikelompokkan ke dalam biaya kualitas atau tidak. Hal ini dilakukan karena selama ini perusahaan belum pernah melakukan pengukuran biaya kualitas. Jadi dalam analisis ini dapat dijadikan konsep dalam pengukuran biaya yang dapat digunakan oleh CV. Black Cup Indo Utama Manado.

1. Biaya bahan baku. Dalam menganalisis biaya bahan baku langkah pertama yang akan diuji adalah apakah didalam proses pengadaan bahan baku terdapat unsur biaya pencegahan (prevention cost), biaya penilaian (appraisal cost) atau biaya kegagalan internal maupun eksternal. Perusahaan dalam rangka memperoleh bahan baku dan sebelum bahan baku itu digunakan terdapat prosedur yang dilaksanakan oleh karyawan tertentu untuk melakukan pemeriksaan atau pengujian bahan baku serta melihat apakah bahan baku yang diantarkan oleh pemasok sesuai dengan kualitas yang dipesan atau tidak. Hal ini menggambarkan bahwa kegiatan melakukan inspeksi bahan baku dalam menguji kualitas bahan baku sudah dilakukan oleh perusahaan akan tetapi perusahaan tidak menyadari telah melakukan kegiatan biaya kualitas dan perusahaan juga tidak melakukan pemilahan. Pemilahan harus dilakukan oleh perusahaan mengingat pemilahan ini memerlukan waktu dan biaya. Dalam penulisan skrispi ini tidak dilakukan pemilahan tapi hanya mendeteksi apakah komponen-komponen biaya yang ada pada perusahaan berhubungan dengan biaya kualitas atau tidak. Dengan melihat kegiatan pengadaan biaya bahan baku pada perusahaan tersebut, maka dapat dikatakan bahwa biaya bahan baku merupakan bagian dari biaya pencegahan (prevention cost).

2. Biaya tenaga kerja. Biaya tenaga kerja tersebut tidak masuk dalam kategori biaya kualitas karena tidak berhubungan dengan mempertahankan dan meningkatkan jasa dan produk. Walaupun biaya tenaga kerja berhubungan dengan jasa akan tetapi yang masuk dalam kategori biaya kualitas yaitu biaya pelatihan tenaga kerja/training tenaga kerja karena dengan melakukan kegiatan pelatihan tenaga kerja/training tenaga kerja perusahaan dapat mempertahankan dan meningkatkan jasa sesuai dengan definisi biaya kualitas yang ada.

3. Biaya operasional. Biaya operasional tidak masuk dalam kategori biaya kualitas karena tidak berhubungan dengan mempertahankan dan meningkatkan jasa dan produk. 
4. Biaya renovasi. Biaya renovasi tidak masuk dalam kategori biaya kualitas karena tidak berhubungan dengan mempertahankan dan meningkatkan jasa dan produk.

5. Biaya pengerjaan ulang. Biaya ini dikelompokkan menjadi biaya kegagalan internal karena biaya kegagalan internal terjadi karena produk dan jasa yang dihasilkan tidak sesuai dengan spesifikasi atau kebutuhan pelanggan. Dalam biaya kegagalan internal terdapat kegiatan pengerjaan ulang, kegiatan pengerjaan ulang sangat diperlukan untuk memperbaiki kualitas produk yang ada seperti memperbaiki pesanan jika pesanan tidak sesuai dengan permintaan konsumen. Dengan demikian dapat dikatakan bahwa biaya pengerjaan ulang merupakan bagian dari biaya kegagalan internal.

Berdasarkan hasil analisis diatas dapat disimpulkan sementara bahwa pada CV. Black Cup Indo Utama ternyata sudah terdapat biaya kualitas yang berhubungan dengan biaya pencegahan (prevention cost) dan biaya kegagalan internal. Sedangkan, yang berhubungan dengan biaya penilaian (appraisal cost) dan biaya kegagalan eksternal belum ditemukan pada perusahaan tersebut.

Analisis pelaporan biaya pada CV. Black Cup Indo Utama. Berdasarkan penelitian yang dilaksanakan pada CV. Black Cup Indo Utama terdapat laporan-laporan yang mendukung jalannya perusahaan yaitu terdiri dari laporan kas masuk dan laporan kas keluar. Dimana laporan kas masuk berisi aliran sumber-sumber dari mana kas diperoleh/penerimaan tunai dari penjualan. Sedangkan, laporan kas keluar berisi tentang kebutuhan kas untuk pembayaran-pembayaran kegiatan operasional perusahaan. Laporan-laporan diatas belum bisa digunakan sebagai alat pengendalian biaya kualitas dikarenakan perusahaan belum membuat dan menyajikan laporan biaya kualitas secara terpisah. Dengan membuat laporan biaya kualitas maka perusahaan dapat mengetahui apakah sistem pengendalian kualitas yang telah diterapkan berjalan efektif dan efisien. Laporan biaya kualitas merupakan informasi yang menjadi dasar penting dalam proses pembuatan keputusan mengingat pelaporan biaya kualitas dapat berguna dalam penurunan biaya kualitas. Langkah pertama dalam membuat pelaporan biaya kualitas yaitu perusahaan harus menentukan biaya kualitas sesungguhnya untuk setiap komponen kualitas. Langkah berikutnya perusahaan harus mengelompokkan komponen-komponen biaya kualitas tersebut dalam kelompok-kelompok biaya kualitas yang terdiri dari biaya pencegahan (prevention cost), biaya penilaian (appraisal cost) dan biaya kegagalan baik internal maupun eksternal.

Setelah dilakukan penyusunan pelaporan biaya kualitas tahunan, perusahaan harus menganalisis pelaporan biaya kualitas dengan menggunakan dasar penjualan kemudian menganalisis pelaporan biaya kualitas dengan menggunakan metode one year period yaitu membandingkan biaya kualitas yang dikeluarkan perusahaan tahun ini dengan tahun sebelumnya dan langkah terakhir yang harus dilakukan oleh perusahaan yaitu menganalisis pelaporan biaya kualitas dengan metode multiple period trend yaitu membandingkan tren biaya kualitas selama beberapa tahun untuk mengetahui apakah biaya-biaya kualitas yang telah dikelompokkan mengalami penurunan biaya kualitas atau mengalami peningkatan biaya kualitas. Dengan demikian, perusahaan dapat melakukan pengendalian biaya kualitas jika CV. Black Cup Indo Utama menyajikan dan membuat pelaporan biaya kualitas seperti yang sudah dijelaskan diatas.

\section{KESIMPULAN DAN SARAN}

\subsection{Kesimpulan}

Berdasarkan hasil penelitian dan pembahasan yang telah dilaksanakan pada CV. Black Cup Indo Utama dapat diambil kesimpulan sebagai berikut:

1. CV. Black Cup Indo Utama dalam pengukuran biaya kualitas belum melakukan pengklasifikasian biaya-biaya yang ada diperusahaan ke dalam komponen-komponen 
pengelompokkan biaya kualitas yang terdiri dari biaya pencegahan (prevention cost), biaya penilaian (appraisal cost) dan biaya kegagalan baik internal maupun eksternal.

2. CV. Black Cup Indo Utama dalam pelaporan biaya kualitas belum membuat dan menyajikan laporan biaya kualitas secara terpisah, oleh karena itu perusahaan belum bisa mengendalikan biaya kualitas.

\subsection{Saran}

Saran yang dapat dipertimbangkan sebagai masukan untuk dilakukan oleh CV. Black Cup Indo Utama adalah sebagai berikut:

1. CV. Black Cup Indo Utama diharapkan mulai melakukan pengklasifikasian biaya-biaya yang ada di perusahaan, ke dalam komponen-komponen pengelompokkan biaya kualitas yang terdiri dari biaya pencegahan (prevention cost), biaya penilaian (appraisal cost) dan biaya kegagalan baik internal maupun eksternal.

2. CV. Black Cup Indo Utama sebaiknya mulai mempertimbangkan untuk membuat laporan biaya kualitas sehingga dapat melakukan pengendalian atas kualitas produk secara lebih baik agar tercipta suatu efektifitas dan efisiensi biaya kualitas.

3. CV. Black Cup Indo Utama diharapkan dapat melakukan pengendalian biaya kualitas secara terus menerus serta melakukan koordinasi antara pihak-pihak terkait dalam kualitas produk.

\section{DAFTAR PUSTAKA}

Clements, R. B. (1993). Quality Manager's Complete Guide to ISO (9000). (Interpretation, application, implementation, registration, and benefits of the ISO 9000 standard). Prentice Hall.

Dunia, F. A., Abdullah, W., \& Sasongko, C. (2012). Akuntansi biaya. Jakarta: Salemba Empat.

Fayol, H. (2013). Pengantar administrasi dan fungsi-fungsi manajemen. Jakarta: PT. Elex Media.

Garrison, R. H., Noreen, E. W., \& Brewer, P. C. (2013). Akuntansi manajerial, buku 2, Edisi 14. Jakarta: Salemba Empat.

Hansen, D, R., \& Mowen, M, M. (2013). Akuntansi manajerial, buku 2, Edisi 8. Jakarta: Salemba Empat.

Lestianingrum, D. (2016). Pengendalian kualitas melalui kualitas pengukuran dan pelaporan biaya kualitas (Studi kasus pada UD Guyub Santoso Blitar-Blitar). Jurnal STIE: Kesuma Negara Blitar, 3(1), 24-42. http://journal.stieken.ac.id/index.php/ritmik/article/view/252

Raiborn, C. A., \& Kinney, M. R. (2011). Akuntansi biaya dasar dan pengembangan. Edisi Tujuh. Jakarta: Salemba Empat.

Setiawan, T., \& Ahalik. (2014). Akuntansi biaya dan manajemen. Jakarta: PT. Bhuana Ilmu Populer.

Simamora, H. (2012). Manajemen sumber daya manusia. Yogyakarta: STIEY.

Siregar, B., Suripto, B., Hapsoro, D., Loe, E. W., \& Biyanto, F. (2013). Akuntansi manajemen. Jakarta: Salemba Empat.

Sugiyono. (2014). Metode penelitian kuantitatif, kualitatif dan R\&D. Bandung: Alfabeta.

Sukmadinata. (2013). Metode penelitian pendidikan. Bandung: PT Remaja Rosdakarya.

Sunyoto, D. (2012). Dasar-dasar manajemen pemasaran, Edisi Kesatu. Yogyakarta: PT Buku Seru.

Supriyono. (2011). Akuntansi biaya pengumpulan biaya dan penentuan harga pokok produk, Edisi Kedua. Yogyakarta: BPFE Universitas Gajah Mada. 
Supriyono. (2010). Akuntansi biaya perencanaan dan pengendalian biaya serta pembuatan keputusan. Yogyakarta: BPFE

Tjiptono, F., \& Chandra, G. (2011). Service quality and satisfaction, Edisi Ketiga. Yogyakarta: Andi. 